\title{
Differentiation Affects the Release of Exosomes from Colon Cancer Cells and Their Ability to Modulate the Behavior of Recipient Cells
}

\author{
Donatella Lucchetti, ${ }^{*}$ Federica Calapà, ${ }^{*}$ Valentina Palmieri, ${ }^{\dagger}$ Caterina Fanali, ${ }^{*}$ Federica Carbone, ${ }^{*}$ Alfredo Papa, \\ Ruggero De Maria, ${ }^{*}$ Marco De Spirito, ${ }^{\dagger}$ and Alessandro Sgambato*
}

From the Institutes of General Pathology* and Physics, ${ }^{\dagger}$ and the Gastroenterology Unit, ${ }^{\ddagger}$ Università Cattolica del Sacro Cuore, Rome, Italy

\author{
Accepted for publication \\ March 4, 2017. \\ Address correspondence to \\ Alessandro Sgambato, M.D., \\ Ph.D., Largo Francesco \\ Vito 1, 00168 Rome, Italy. \\ E-mail: alessandro.sgambato@ \\ unicatt.it.
}

\begin{abstract}
Exosomes are involved in intercellular communication. We previously reported that sodium butyrate-induced differentiation of HT29 colon cancer cells is associated with a reduced CD133 expression. Herein, we analyzed the role of exosomes in the differentiation of HT29 cells. Exosomes were prepared using ultracentrifugation. Gene expression levels were evaluated by real-time PCR. The cell proliferation rate was assessed by MTT assay and with the electric cell-substrate impedance sensing system, whereas cell motility was assessed using the scratch test and confocal microscopy. Sodium butyrate-induced differentiation of HT29 and Caco-2 cells increased the levels of released exosomes and their expression of CD133. Cell differentiation and the decrease of cellular CD133 expression levels were prevented by blocking multivesicular body maturation. Exosomes released by HT29 differentiating cells carried increased levels of miRNAs, induced an increased proliferation and motility of both colon cancer cells and normal fibroblasts, increased the colony-forming efficiency of cancer cells, and reduced the sodium butyrate-induced differentiation of HT29 cells. Such effects were associated with an increased phosphorylation level of both Src and extracellular signal regulated kinase proteins and with an increased expression of epithelial-to-mesenchymal transition-related genes. Release of exosomes is affected by differentiation of colon cancer cells; exosomes might be used by differentiating cells to get rid of components that are no longer necessary but might continue to exert their effects on recipient cells. (Am J Pathol 2017, 187: 1633-1647; http://dx.doi.org/10.1016/j.ajpath.2017.03.015)
\end{abstract}

Colorectal cancer is the third most common malignancy in males and the second in females worldwide. Unfavorable trends of this cancer are thought to reflect a combination of factors, including changes in dietary patterns, obesity, and an increased prevalence of smoking. ${ }^{1}$ Alimentary fibers exert protective effects against colon carcinogenesis, ${ }^{2}$ and it has been suggested that sodium butyrate $(\mathrm{NaBu})$, a shortchain fatty acid produced by anaerobic bacteria fermentation of dietary fibers preferentially used as an energy source by gut epithelial cells, may inhibit the development of colon cancer. ${ }^{3} \mathrm{NaBu}$ has been shown to inhibit the growth of colonic cancer cells, and to stimulate their apoptosis and differentiation. $^{4-6}$

In 1997, Weigman et $\mathrm{al}^{7}$ identified a novel cholesterolinteracting pentaspan-transmembrane glycoprotein, prominin-1 or CD133, as a surface protein marker of a subset of hematopoietic stem cells and progenitor cells. Ricci-Vitiani et $\mathrm{al}^{8}$ and $\mathrm{O}^{\prime}$ Brien et $\mathrm{al}^{9}$ subsequently identified CD133 as a marker of colon cancer stem cells. CD133 is specifically concentrated in plasma membrane protrusions containing

\footnotetext{
Supported by a Università Cattolica del Sacro Cuore grant (A.S.) and an Italian Association for Cancer Research Loredana Gualandi Sabotti fellowship (D.L.). Dynamic light-scattering and microscopic measurements were performed at the facility Laboratorio Centralizzato di Microscopia Ottica ed Elettronica, Università Cattolica del Sacro Cuore (Rome, Italy).

M.D.S. and A.S. contributed equally to this work as senior authors.

Disclosures: None declared.

Data were presented in part as an Abstract (C30) at the Italian 3rd Joint Meeting of Pathology and Laboratory Medicine, October 4-6, 2016, Montesilvano, Pescara, Italy.
} 
lipid rafts and, more recently, it has been demonstrated that CD133-containing lipid rafts play a pivotal role in the maintenance of stem cell features. ${ }^{10}$ Moreover, CD133 is released from neural progenitor cells, epithelial cells, and hematopoietic stem cells by extracellular vesicles on differentiation. ${ }^{11}$ It has been suggested that the release of CD133-containing vesicles may contribute to cell differentiation by reducing and/or modifying the composition of stem cell-characteristic membrane microdomains within the apical plasma membrane. Bauer et $\mathrm{al}^{12}$ showed that hematopoietic stem cells and progenitor cells, which have the ability to differentiate into mature blood cells, release CD133-containing exosomes concomitant with cellular differentiation. Moreover, Rappa et $\mathrm{al}^{13}$ isolated, from a whole fraction of exosomes released by melanoma cancer cells, only the exosomes positive for CD133: the exposure of bone marrow-derived stromal cells to the exosomes positive for CD133 increased the invasion ability of these cells compared with mock-treated bone marrow-derived stromal cells. These findings support the concept of cancer stem cell-specific lipid rafts holding molecular determinants needed to maintain cancer stem cell/prometastatic properties. We previously reported that $\mathrm{NaBu}$-induced differentiation of HT29 colon cancer cells is associated with loss of CD133 expression. ${ }^{14}$ Thus, it was of interest to verify whether exosome release is affected by colon cell differentiation and whether the release of CD133-containing vesicles might contribute to this phenomenon.

\section{Materials and Methods}

\section{Exosome Purification}

This study largely followed the protocol previously described by Théry et $\mathrm{al}^{15}{ }^{15}$ with some modifications. The exosome purification process can be summarized as follows: cell culture media were centrifuged at $750 \times g$ for $15 \mathrm{mi}-$ nutes, and then at $1500 \times g$ for 5 minutes. Supernatants were saved and centrifuged at $14,000 \times g$ for 45 minutes. Supernatants were transferred to fresh tubes and centrifuged at $100,000 \times g$ for exosome purification. Exosome pellets were resuspended in phosphate-buffered saline and used for the treatment of cells or to prepare cell extracts for Western blot analysis. The Bradford assay and dynamic light scattering were used for the quantitative evaluation of exosome, as previously described. ${ }^{15,16}$

\section{Cell Culture}

Rat-1 (normal rodent fibroblasts), HT29, Caco-2, and HCT116 (human colorectal adenocarcinoma) cell lines were used for in vitro studies and were cultured in Eagle's minimum essential medium and in Dulbecco's modified Eagle's medium, respectively, supplemented with $10 \%$ fetal bovine serum, $1 \%$ penicillin-streptomycin, and $2 \mathrm{mmol} / \mathrm{L} \mathrm{L}$-glutamine at $37^{\circ} \mathrm{C}$ in a humid $5 \% \mathrm{CO}_{2}$ atmosphere.
Dynamic Light Scattering and Transmission Electron Microscopy

Dynamic light-scattering measurements were performed using a Zetasizer Nano ZS apparatus (Malvern Instruments Ltd, Worcestershire, UK). Data for each sample were collected on a continuous basis for 12 minutes in sets of four measurements for each sample. Peak-intensity analyses were used to determine hydrodynamic radius by number distribution, described elsewhere. ${ }^{16}$

For morphological study, we used transmission electron microscopy: isolated exosomes were fixed, adding Karnovsky EM fixative (2\% formaldehyde and $2.5 \%$ glutaraldehyde in $0.1 \mathrm{~mol} / \mathrm{L}$ sodium cacodylate buffer, $\mathrm{pH}$ 7.4.) to the suspension in 1:1 ratio for 1 hour. Samples were then placed on Formvar-carbon-coated grids and air dried for 10 minutes. After being rinsed with distilled water, the specimens were post fixed in $1.5 \%$ osmium tetroxide in $0.1 \mathrm{~mol} / \mathrm{L}$ cacodylate buffer ( $\mathrm{pH} 7.3$ ), were allowed to dry, and were observed with a Zeiss Libra 120 (Zeiss NTS $\mathrm{GmbH}$, Oberkochen, Germany).

\section{Western Blot Analysis}

For Western blot analysis, cells or exosomal preparations were lysed using lysis buffer $(50 \mathrm{mmol} / \mathrm{L}$ Tris- $\mathrm{HCl}, \mathrm{pH} 7.2$, $150 \mathrm{mmol} / \mathrm{L} \mathrm{NaCl}, 100 \mathrm{mmol} / \mathrm{L} \mathrm{NaF}, 100 \mathrm{mmol} / \mathrm{L}$ sodium pyruvate, and $1 \%$ Triton $\mathrm{X}-100$ ) containing protease inhibitors, $2 \mathrm{mmol} / \mathrm{L}$ phenyl methyl sulfonyl fluoride, $10 \mathrm{mg} /$ $\mathrm{mL}$ aprotinin, and $2 \mathrm{mmol} / \mathrm{L} \mathrm{Na}_{3} \mathrm{VO}_{4}$. Extracted protein $(10 \mu \mathrm{g})$ was separated by SDS-PAGE, transferred to immobilon-P membranes, and analyzed using the enhanced chemiluminescence kit for Western blotting detection (Amersham Pharmacia Biotech, Milan, Italy), as previously described. ${ }^{15}$ Primary monoclonal antibodies were used following suppliers' instructions and included the following: mouse anti-human monoclonal CD63 (dilution, 1:1000; Santa Cruz Biotechnology, Inc., Dallas, TX), mouse monoclonal anti-human CD133 (dilution, 1:200; Miltenyi Biotec S.r.l., Bologna, Italy), rabbit polyclonal anti-human caveolin1 (Cav-1; dilution, 1.500; Santa Cruz Biotechnology, Inc.), rabbit polyclonal anti-human Src (dilution, 1:1000; Cell Signaling Technology, Milan, Italy), rabbit polyclonal antihuman pSrc (dilution, 1:1000; Cell Signaling Technology), rabbit polyclonal anti-human extracellular signal regulated kinase (ERK; dilution, 1:1000; Cell Signaling Technology), and rabbit polyclonal anti-human pERK (dilution, 1:1000; Cell Signaling Technology).

\section{Cell Viability Assay}

Cell viability was evaluated by using an MTT assay, as previously described. ${ }^{17}$ Briefly, $1 \times 10^{4}$ cells were plated in $100 \mu \mathrm{L}$ of medium in 96-well microtiter plates and incubated for 24 hours. Medium was then replaced, and cells were incubated for 48 hours with exosomes or phosphate-buffered 
saline, as solvent control. MTT solution was added to each well and incubated at $37^{\circ} \mathrm{C}$ for 2 hours. The amount of MTT formazan product was determined by measuring absorbance with a microplate reader at a test wavelength of $570 \mathrm{~nm}$ and a reference wavelength of $630 \mathrm{~nm}$.

\section{ALP Assay}

Alkaline phosphatase (ALP) activity, a marker of colon differentiation, was assessed by a kinetic assay measuring the conversion of the colorless p-nitrophenyl phosphate in pnitrophenol, which is yellow in basic solutions, as previously reported. ${ }^{14}$ Briefly, total cellular lysates were prepared in phosphate-buffered saline with $10 \%$ Triton- $\mathrm{X}$ and aliquots of $100 \mu \mathrm{g}$ of protein were assayed for ALP activity by addition of p-nitrophenyl phosphate substrate. ${ }^{17}$ Spectrophotometric readings were taken on a SpectraMax1 Plus 384 spectrophotometer (Molecular Devices Corp., Sunnyvale, CA) and were analyzed using the Softmax Pro Software version 4.3 (Molecular Devices Corp.) to obtain the $\mathrm{V}_{\max }$ values. Data shown are the means $\pm \mathrm{SD}$ of three independent assays.

\section{ECIS System}

An electric cell-substrate impedance sensing (ECIS) system (Applied Bio-Physics Inc., Troy, NY) was used to monitor real-time cell growth and motility. Briefly, cells $\left(2 \times 10^{5}\right.$ HCT116 or $1 \times 10^{5}$ Rat-1) were seeded in $400 \mu \mathrm{L}$ of medium in arrays containing gold electrodes (Applied Biophysics 8W10E; Linea SisLab, Milan, Italy). Impedance, which is affected by the number and the morphology of cells covering the electrode, was monitored for a maximum of 48 hours. The wound assay was performed using confluent cultures exposed to a current pulse of $40-\mathrm{kHz}$ frequency for a duration of 30 seconds and then monitoring impedance for the subsequent 48 hours.

\section{Colony-Forming Efficiency and Soft Agar Assay}

For colony-forming efficiency, $500 \mathrm{HCT} 116$ cells were plated onto 100-mm culture dishes in Dulbecco's modified Eagle's medium supplemented with $10 \%$ fetal bovine serum, $1 \%$ penicillin-streptomycin, and $2 \mathrm{mmol} / \mathrm{L} \mathrm{L}$-glutamine at $37^{\circ} \mathrm{C}$, in a humid 5\% $\mathrm{CO}_{2}$ atmosphere. After 2 weeks, the colonies were fixed, stained with crystal violet, and counted. ${ }^{18}$

For soft agar assays, HCT116 cells were suspended in medium containing $0.3 \%$ agar and overlaid on $0.6 \%$ agar in 6 -well plates $\left(2 \times 10^{4}\right.$ cells/well). After 3 weeks, colonies were counted and imaged. ${ }^{19}$

\section{Confocal Microscopy}

HT29 exosomes were labeled with BODIPY TR ceramide (Life Technologies, Monza, Italy) following the protocol suggested by the supplier, with slight modifications. In brief, a $1 \mathrm{mmol} / \mathrm{L}$ dimethyl sulfoxide stock solution was prepared and $1 \mu \mathrm{L}$ was added to $100 \mu \mathrm{L}$ exosome sample and mixed to obtain a final dye concentration of $10 \mu \mathrm{mol} / \mathrm{L}$. Samples were then centrifuged at $37^{\circ} \mathrm{C}$ for 20 minutes, and to remove the excess of unincorporated dye from the exosome fraction, the supernatant was discarded after further ultracentrifugation at $100,000 \times g$ for 1 hour. The Spectra Max Gemini EM Microplate Reader (Molecular Devices Corp.) was used to analyze the efficiency of exosome labeling using an excitation wavelength of $595 \mathrm{~nm}$. Exosome uptake by cells was quantified by staining cells with fluorescein isothiocyanate-labeled phalloidin (Life Technologies) and DAPI (Fluoromount $G$ with DAPI; Electron Microscopy Sciences, Hatfield, PA) and imaging with a CARV II spinning-disk microscope (Crisel Instruments, Rome, Italy), as reported previously. ${ }^{20}$ To evaluate the influence of exosomes on the migratory ability of tumor cells, confocal microscopy was performed in a temperature-controlled environment (temperature $=37^{\circ} \mathrm{C}$ ) on cells cultured for 24 hours in 35-mm glass-bottom Petri dishes (GmbH; Ibidi, Planegg/Martinsried, Germany). Cells labeled with the fluorescent probe Laurdan (6-lauroyl,1-2-dimethylamino naphthalene) have been imaged with Nikon A1+ (Nikon, Melville, NY). Cell trajectories were calculated by using ImageJ software version 1.41 (NIH, Bethesda, MD; http:// imagej.nih.gov/ij), as reported previously. ${ }^{21}$

\section{Quantitative Real-Time PCR}

Total RNA was extracted using the Ribo Pure Kit Ambion (Life Technologies) and was reverse transcribed into cDNA

Table 1 Sequences of Primers Used to Analyze Gene Expression Levels

\begin{tabular}{|c|c|}
\hline Gene & Primer sequence \\
\hline \multirow[t]{2}{*}{ VEGF } & Forward: 5'-TGCAGATTATGCGGATCAAACC-3' \\
\hline & Reverse: 5'-TGCATTCACATTTGTTGTGCTGTA-3' \\
\hline \multirow[t]{2}{*}{ CAV1 } & Forward: 5'-GATGACGTGGTCAAGATTGACT-3' \\
\hline & Reverse: 5'-CCAGTATTTCGTCACAGTGAAG-3' \\
\hline \multirow[t]{2}{*}{ TGF $\beta 1$} & Forward: 5'-CCCAGCATCTGCAAAGCTC-3' \\
\hline & Reverse: 5'-GTCAATGTACAGCTGCCGCA-3' \\
\hline \multirow[t]{2}{*}{$\mathrm{CDH} 1$} & Forward: 5'-CGAGAGCTACACGTTCACGG-3' \\
\hline & Reverse: 5'-GGGTGTCGAGGGAAAAATAGG-3' \\
\hline \multirow[t]{2}{*}{ VIM } & Forward: 5'-GTCCACTGAGTACCGGAGAC-3' \\
\hline & Reverse: 5'-TCCATTTCACGCATCTGGCG-3' \\
\hline \multirow[t]{2}{*}{ ACTA2 } & Forward: 5'-GATCATGCGTCTGGACTTGG-3' \\
\hline & Reverse: $5^{\prime}-$ CCAGGGAAGAAGAGGAAGCA-3' \\
\hline \multirow[t]{2}{*}{ ZEB1 } & Forward: 5'-CTCCCTGTGCAGTTACACCT-3' \\
\hline & Reverse: 5'-TTACACCCAGACTGCGTCAC-3' \\
\hline \multirow[t]{2}{*}{$C D C 42$} & Forward: 5'-GCAGGGCAAGAGGATTATGAC-3' \\
\hline & Reverse: 5'-CAGTGGTGAGTTATCTCAGGC-3' \\
\hline \multirow[t]{2}{*}{ RHOA } & Forward: 5'-CCATCGACAGCCCTGATAGTT-3' \\
\hline & Reverse: 5'-GCCTTGTGTGCTCATCATTCC-3' \\
\hline \multirow[t]{2}{*}{$R A C 1$} & Forward: 5'-AAGTGGTATCCTGAGGTGCG-3' \\
\hline & Reverse: 5'-TAGACCCTGCGGATAGGTGA-3' \\
\hline \multirow[t]{2}{*}{ ACTB } & Forward: 5'-TCTACAATGAGCTGCGTGTGG-3' \\
\hline & Reverse: 5'-CTGGATAGGAACGTACAT-3' \\
\hline
\end{tabular}


A

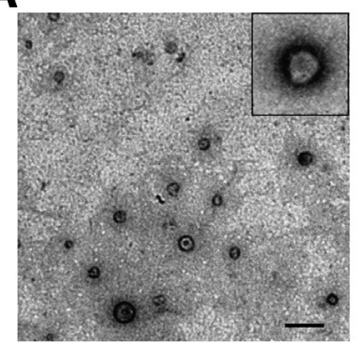

B



C

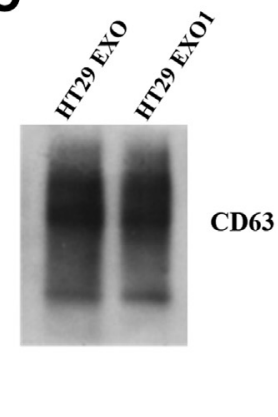

D

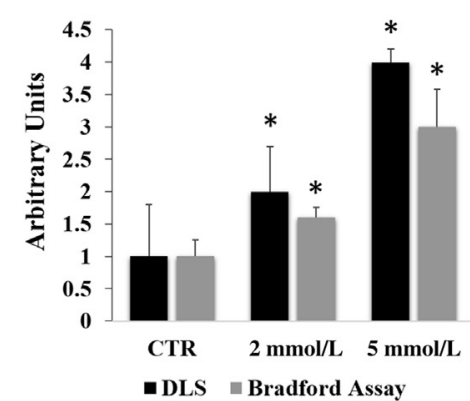

Figure 1 Exosome release increases during NaBu-induced differentiation of HT29 cells in a dose-dependent manner. A: Transmission electron microscopy for morphology and size characterization of exosomes isolated from HT29 cell culture conditioned medium. Exosomes appear small ( 30 to $100 \mathrm{~nm}$ ) and with a typical cup-shaped morphology. The inset shows a single exosome at higher magnification. B: Arbitrary curve of exosome size distribution expressed in diameter. C: Western blot analysis with the anti-CD63 antibody, used as a marker of exosomes, confirming their correct isolation. D: An increased amount of exosomes are detected in the culture medium of HT29 cells exposed to NaBu for 48 hours, as assessed using both dynamic light scattering (DLS) and quantification of exosome-extracted proteins (Bradford). Results also demonstrate a good concordance between the two methods. Data are expressed as means \pm SEM (D). Results of three independent experiments. ${ }^{*} P<0.05$ versus control untreated (CTR) cells. Scale bar $=200 \mathrm{~nm}($ A).

using the iScript cDNA Synthesis kit (Bio-Rad Laboratories S.r.l., Segrate, Milan, Italy). The primers adopted for gene expression analysis were the following: transforming growth factor- $\beta$, E-cadherin, vimentin, Zeb1, vascular endothelial growth factor, CD133, Cav-1, and $\beta$-actin as housekeeping gene (Table 1). Analysis was performed using the CFX96 Touch Real-Time PCR Detection System
(Bio-Rad Laboratories S.r.l.), and the acquisition and data processing were performed using the CFX Manager software version 1.6 (Bio-Rad Laboratories S.r.l.). For miRNA analyses, the qScript miRNA cDNA Synthesis Kit (Quanta Biosciences, Beverly, MA) was used for retrotranscription. The PerfeCta miRNA assay (Quanta Biosciences) was used to analyze three miRNAs: miR-24, miR-26a, and miR-27a.
A

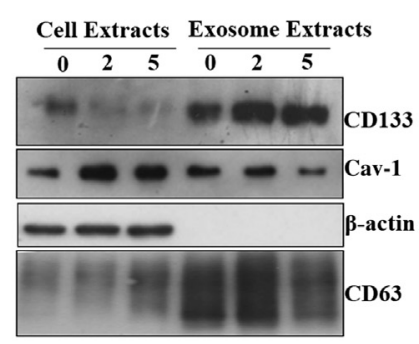

D



B

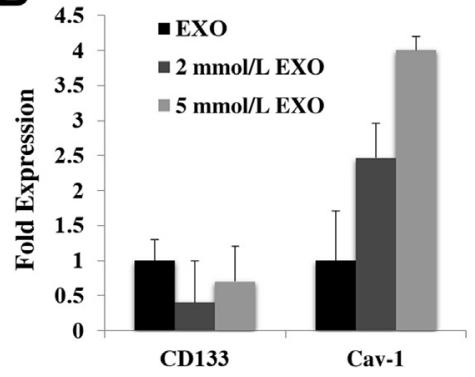

E

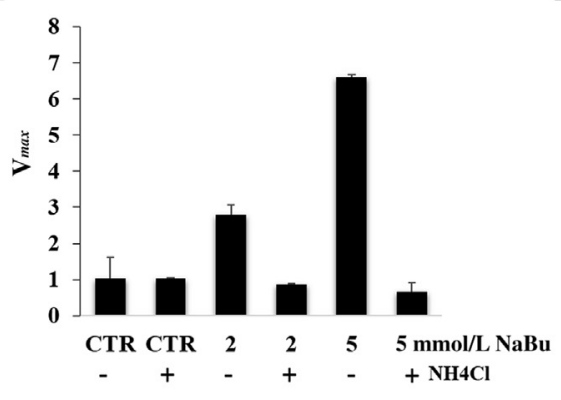

C Cell Extracts

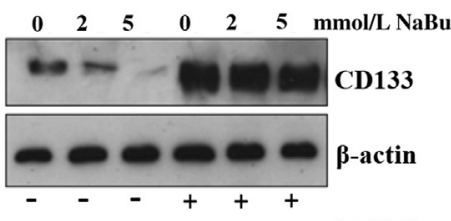

$\mathbf{F}$

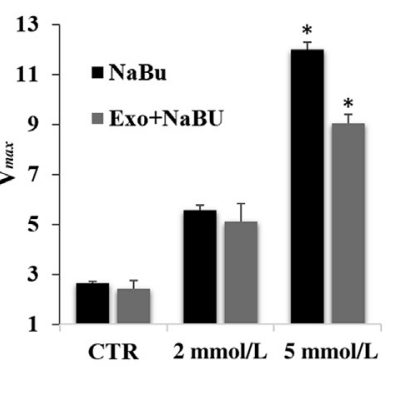

Figure 2 CD133-enriched exosomes are released during differentiation of HT29 cells. A: Western blot analysis of CD133 and caveolin-1 (Cav-1) expression in protein extracts isolated from cells (cell extracts) or exosomes (exosome extracts) collected from cell culture exposed to the indicated amount of $\mathrm{NaBu}(0,2$, and $5 \mathrm{mmol} / \mathrm{L}$ ) for 48 hours. B: Quantitative real-time PCR analysis of CD133 and Cav-1 expression levels in RNA extracts isolated from exosomes collected from cell cultures control (EXO) or exposed to $2\left(2 \mathrm{mmol} / \mathrm{L}\right.$ EXO) and $5\left(5 \mathrm{mmol} / \mathrm{L} \mathrm{EXO)} \mathrm{NaBu} \mathrm{for} 48\right.$ hours. Treatment with $20 \mathrm{mmol}^{\mathrm{L}} \mathrm{NH}{ }_{4} \mathrm{Cl}$, which blocks multivesicular body maturation, prevents the reduction of CD133 expression levels (C), reduces the release of exosomes (D), and inhibits differentiation of HT29 colon cancer cells, as assessed by evaluating ALP activity $\left(\mathrm{V}_{\max }\right)(\mathbf{E})$. F: NaBu-induced differentiation of HT29 cells is inhibited by incubation with exosomes (Exo) isolated from 48-hour conditioned medium of differentiated HT29 cells. Data are expressed as means \pm SEM. ${ }^{\star} P<0.05$ versus control untreated (CTR) cells. 



C
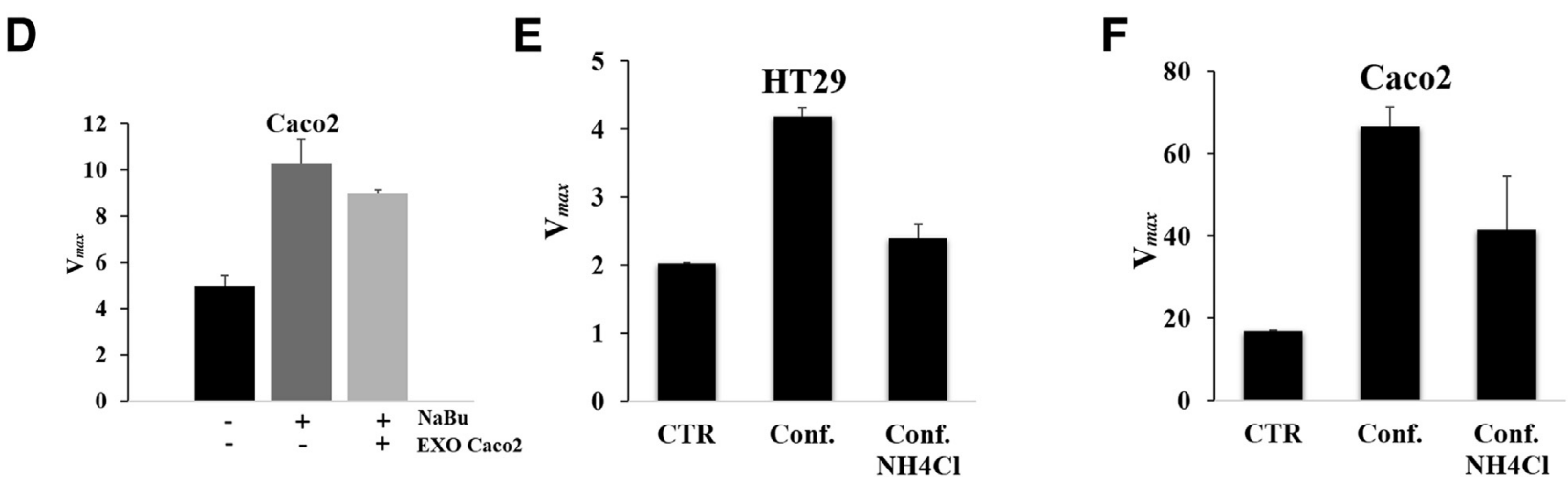

Figure 3 Release of CD133-enriched exosomes increases during NaBu-induced differentiation of Caco-2 cells. A: An increased amount of exosomes are detected in the culture medium of Caco-2 cells exposed to $5 \mathrm{mmol} / \mathrm{L} \mathrm{NaBu}$ for 48 hours, as assessed using both dynamic light scattering (DLS) and quantification of exosome-extracted proteins (Bradford). Treatment with $20 \mathrm{mmol} / \mathrm{L} \mathrm{NH}{ }_{4} \mathrm{Cl}$, which blocks multivesicular body maturation, inhibits differentiation of Caco-2 colon cancer cells, as assessed by evaluating ALP activity $\left(\mathrm{V}_{\max }\right)(\mathbf{B})$ and prevents the reduction of cellular CD133 expression levels (C). D: Incubation with exosomes (EXO Caco2) isolated from 48-hour conditioned medium of differentiated Caco-2 cells inhibits NaBu-induced differentiation of Caco-2 cells. Treatment with $20 \mathrm{mmol} / \mathrm{L} \mathrm{NH}_{4} \mathrm{Cl}$, which blocks multivesicular body maturation, inhibits confluence (conf.)-induced spontaneous differentiation of both $\mathrm{HT} 29$ (E) and Caco-2 colon cancer $(\mathbf{F})$ cells, as assessed by evaluating ALP activity $\left(\mathrm{V}_{\max }\right)$. Data are expressed as means \pm SEM. CTR, control untreated.

\section{Statistical Analysis}

Data shown are the means $\pm \mathrm{SD}$ of three independent assays. Statistical differences between groups were analyzed using $t$-test. The difference was considered statistically significant at $P<0.05$.

\section{Results}

\section{NaBu-Induced Differentiation of HT29 Cells Is Associated with an Increased Release of Exosomes}

We initially set up the protocol for the isolation of exosome from cell culture media. Isolation of exosome, from 48-hour conditioned medium of HT29 cells, was confirmed by transmission electron microscopy as well as by size measurement using dynamic light scattering and by Western blot analysis of protein extracts using the exosome-specific marker CD63 (Figure 1, A-C). We previously reported that HT29 human colorectal cells undergo differentiation when exposed to $\mathrm{NaBu}(2$ or $5 \mathrm{mmol} / \mathrm{L}) .{ }^{14}$ To determine whether $\mathrm{NaBu}$-induced differentiation modulates the release of exosomes, we collected exosomes from 48-hour conditioned medium of untreated and $\mathrm{NaBu}(2$ and $5 \mathrm{mmol} / \mathrm{L}$ )-treated
HT29 cells and quantified them by assessing exosomeextracted proteins (Bradford) and using dynamic light scattering, as previously described. ${ }^{16}$ Levels of exosomes isolated from HT29 treated with $\mathrm{NaBu}(2$ or $5 \mathrm{mmol} / \mathrm{L}$ ), normalized to cell number, were significantly higher when compared to those isolated from untreated cells (Figure 1D).

\section{NaBu-Induced Differentiation of HT29 Cells Is Associated with a Reduced Cellular Expression of CD133 and Is Prevented by Inhibition of Exosome Release}

CD133 is a colon cancer stem cell marker whose expression decreases during differentiation of HT29 cells. ${ }^{14}$ We evaluated whether the release of exosome might contribute to the reduction of CD133 expression during NaBu-induced differentiation. We found that although the expression of cellular CD133 molecule decreased in cells undergoing differentiation, its levels increased on exosome released by differentiating cells (Figure 2A). This effect was specific because it was not observed for other proteins, such as Cav-1, whose expression increased in cells while decreasing on exosome during differentiation (Figure 2A). Expression levels of CD133 and 


\section{A}
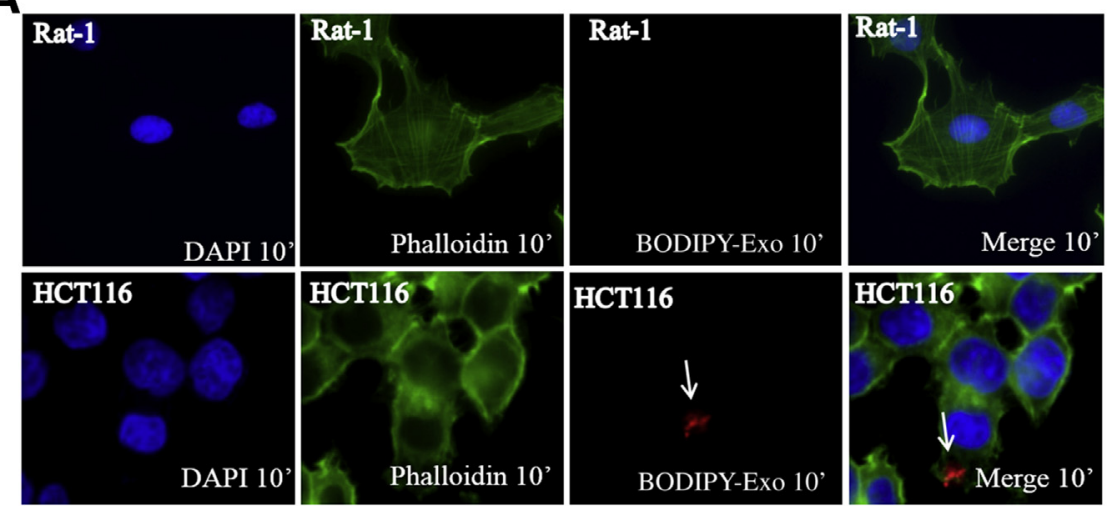

B
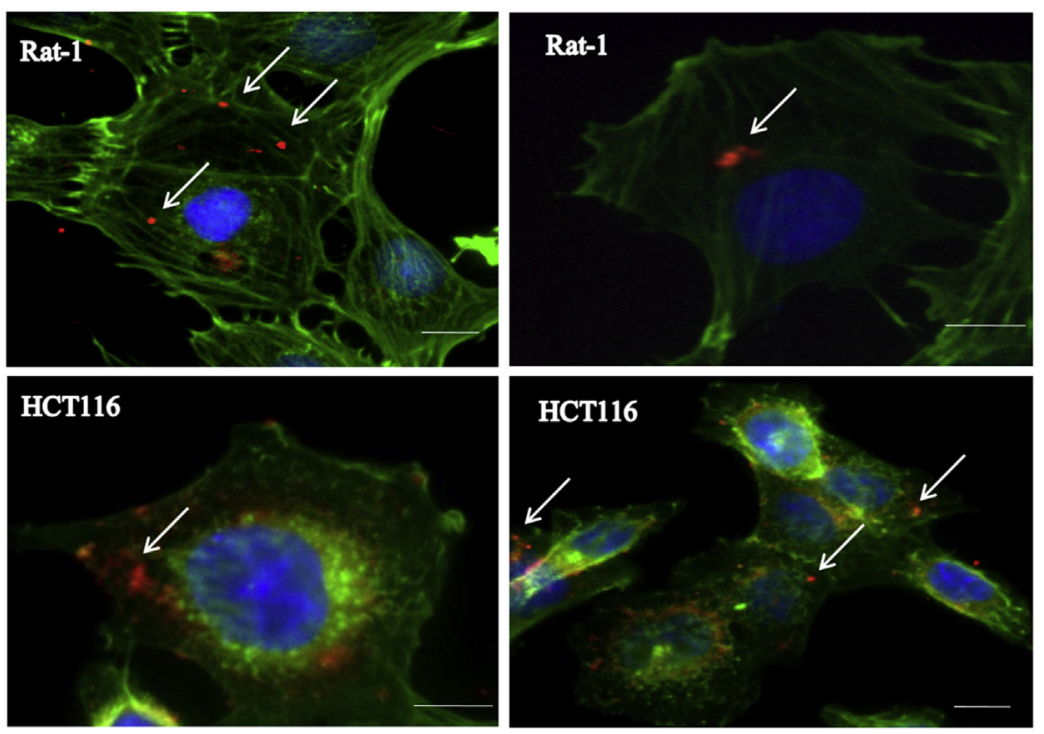

Figure 4 Uptake of exosomes in Rat-1 and HCT116 cells. Representative examples of staining after 10 (A) or 30 (B) minutes of incubation with HT29 cell-released exosomes. Blue = nuclei (DAPI); green $=$ actin (phalloidin); red = exosomes (BODIPYceramide). Arrows indicate uptaken exosomes stained with BODIPY-ceramide. Scale bars $=10 \mu \mathrm{m}$ (B). Original magnification, $\times 63(\mathrm{~A})$.
Cav-1 in exosome fractions were also evaluated by RT-PCR: interestingly, CD133 mRNA decreased, whereas Cav-1 mRNA increased, during differentiation (Figure 2B).

Multivesicular body maturation is a step essential for exosome formation and release and can be inhibited by ammonium chloride. $^{22}$ To evaluate the role played by exosome release in NaBu-induced differentiation of HT29 cells, differentiating cells were exposed to ammonium chloride and the effects on cell differentiation and exosome release were evaluated. We found that ammonium chloride treatment prevented the reduction of CD133 expression in HT29 cells exposed to $\mathrm{NaBu}$ for 48 hours (Figure 2C). This finding was associated with a reduction in the release of exosomes (Figure 2D) and, interestingly, a reduced differentiation, as assessed by evaluating ALP activity (Figure 2E).

Exosomes can carry a broad number of cargo, including signaling molecules able to affect the behavior of surrounding cells, and it has been reported that they could be also used by cells to get rid of unwanted molecules. ${ }^{23}$ Thus, it was of interest to evaluate whether exosomes released by differentiated cells could have different effects than exosomes released by control-untreated cells, on recipient cells.
We initially tested the effects of exosomes on the $\mathrm{NaBu}$ induced differentiation of the same cells and found that differentiation of HT29 cells was inhibited by incubation with exosomes isolated from 48-hour conditioned medium of differentiated HT29 cells (Figure 2F).

Release of CD133-Enriched Exosomes Increases during Confluence- and NaBu-Induced Differentiation of Caco-2 Cells

The reported findings could be considered general features characterizing the differentiation of colon cancer cells or they might represent idiosyncrasies of the combination HT29/NaBu. To answer to this question, we used the Caco2 human colon cancer cells, a well-established model system, to study cellular differentiation of human enterocytes, because they also differentiate spontaneously into mature colonic epithelium cells when grown as a confluent monolayer or exposed to $\mathrm{NaBu} .{ }^{11}$ We found that, similar to what was observed in HT29 cells, NaBu-induced differentiation of Caco-2 cells was associated with an increased release of exosomes (Figure 3A) and was prevented by treatment with 



Figure 5 HT29-derived exosomes stimulate proliferation of Rat-1 and HCT116 cells. HCT116 (A) and Rat-1 (B) cells were exposed for 48 hours to $1 \mu \mathrm{g}$ of exosomes released by HT29 untreated (EXO) or treated with 2 $\mathrm{mmol} / \mathrm{L}$ (EXO $2 \mathrm{mmol} / \mathrm{L}$ ) or $5 \mathrm{mmol} / \mathrm{L}$ (EXO $5 \mathrm{mmol} / \mathrm{L}$ ) $\mathrm{NaBu}$, and cell viability was assessed by MTT assay or using an electric cell-substrate impedance sensing system. Data are expressed as means \pm SEM. ${ }^{*} P<0.05$ versus control untreated (CTR) cells.

ammonium chloride (Figure 3B). NaBu-induced differentiation of Caco-2 cells was also associated with a reduction in the expression of cellular CD133 level, which was prevented by treatment with ammonium chloride (Figure 3C). Like HT29 cells, we also found that NaBu-induced differentiation of Caco-2 cells was inhibited by incubation with exosomes isolated from 48-hour conditioned medium of differentiated Caco-2 cells (Figure 3D).

To further verify whether differentiation per se induces the reported effects or, alternatively, they are specific to $\mathrm{NaBu}$-induced differentiation, both HT29 and Caco-2 cell cultures were grown to and left at confluence for 8 days to induce their spontaneous differentiation. We found that ALP activity showed a twofold and a threefold increase in confluent HT29 and Caco-2 cells, respectively, and this increase was markedly prevented by treatment with ammonium chloride (Figure 3, E and F).

Overall, these results suggest that the involvement of exosomes is not $\mathrm{NaBu}$ or cell type specific but might play a general role in the differentiation process of human intestinal cancer cells.

\section{Exosomes Isolated from 48-Hour Conditioned Medium of Differentiating HT29 Cells Stimulate Proliferation and Enhance the Tumorigenic Potential}

We further investigated the effects of exosomes released by untreated and NaBu-treated HT29 cells on the behavior of potentially surrounding recipient cells (ie, other cancer cells and normal fibroblasts) using the HCT116 human colon cancer cells and the Rat- 1 rodent normal fibroblasts as cell models. The uptake of HT29 cell-derived exosomes by both Rat-1 and HCT116 cells was evaluated by using the fluorescent lipid membrane dye BODIPY-ceramide that stains the exosome fraction. The uptake of exosomes was evident in both cell lines after 30 minutes, but it was already evident after 10 minutes in HCT116 but not in Rat-1 cells (Figure 4).

When HCT116 cell cultures were exposed to $1 \mu \mathrm{g}$ of exosomes released by HT29 untreated or treated for 48 hours with $2 \mathrm{mmol} / \mathrm{L}$ or $5 \mathrm{mmol} / \mathrm{L} \mathrm{NaBu}$, it clearly emerged that all exosomes stimulated cell viability when compared to control untreated cells, with the highest effect exerted by exosomes isolated from differentiated cultures (Figure 5A). Comparable results were also obtained with exosomes released by undifferentiated or $\mathrm{NaBu}$-differentiated cultures of Caco-2 cells (data not shown).

An increased cell viability was also evident in Rat- 1 cells treated with exosomes isolated from both differentiated and

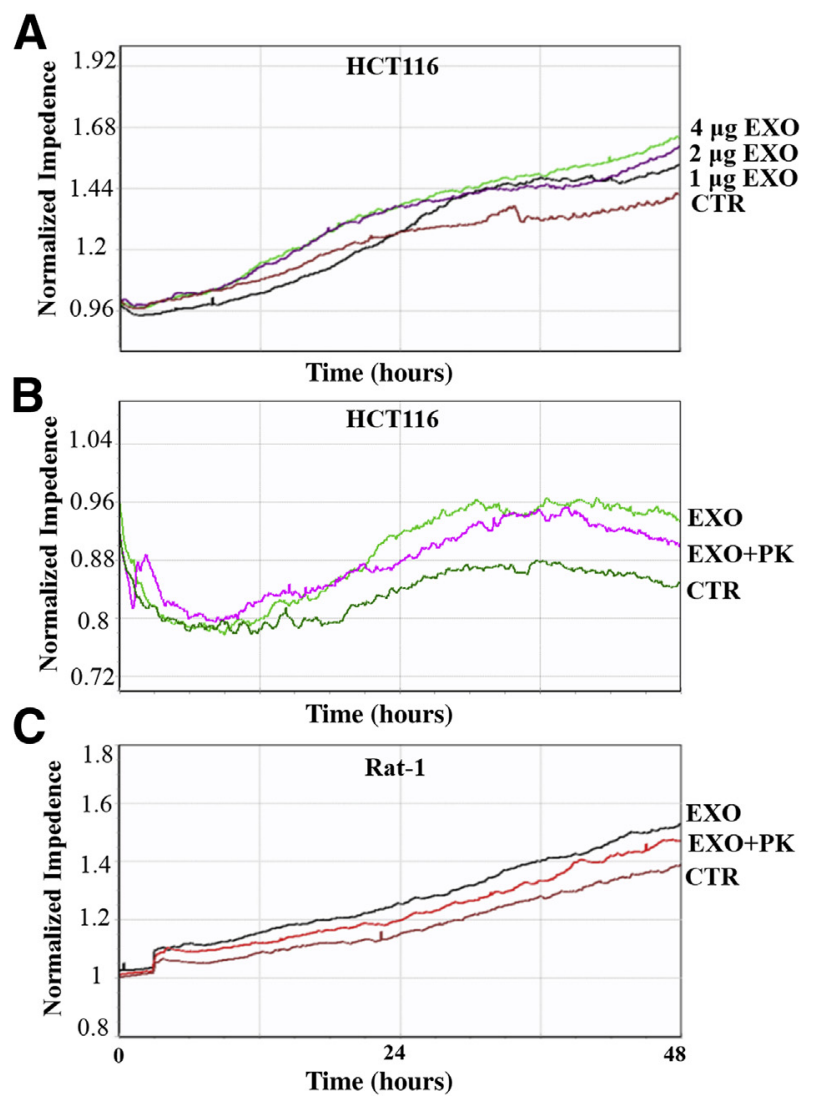

Figure 6 Exosome-induced increase in cell proliferation occurs in a dose-dependent manner and depends on surface proteins. A: The proliferation rate of HCT116 increases, after treatment with exosomes (EXO) isolated from HT29 cells, in a dose-dependent manner (1, 2, and $4 \mu \mathrm{g})$, compared to control untreated cells (CTR), as assessed using the ECIS system. B: Cell proliferation rate was assessed in HCT116 cell cultures untreated (CTR) or exposed to $1 \mu \mathrm{g}$ exosomes isolated from 48-hour conditioned medium of HT29 untreated (EXO) or pretreated with proteinase K (PK). C: Cell proliferation rate was assessed in HCT116 cell cultures untreated (CTR) or exposed to $1 \mu \mathrm{g}$ exosomes isolated from 48-hour conditioned medium of HT29 untreated (EXO) or pretreated with PK. 


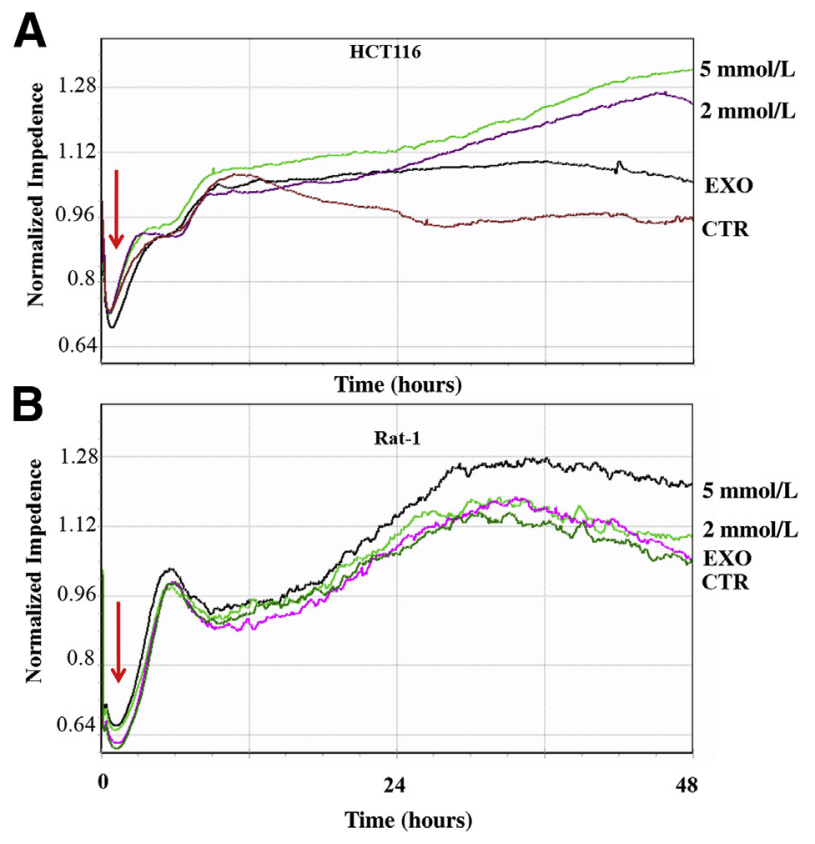

Figure 7 HT29-derived exosomes increase cell motility in both Rat-1 and HCT116 cells. HCT116 (A) and Rat-1 (B) cells were seeded in a confluent manner in ECIS arrays and the next day were exposed to a current pulse of $40-\mathrm{kHz}$ frequency for a duration of 30 seconds to induce wounding. Afterward, the cells were treated with $1 \mu \mathrm{g}$ of exosomes and impedance was then monitored for the subsequent 48 hours. Cell motility was assessed in HCT116 cell cultures untreated (CTR) or exposed to exosomes released by HT29 untreated (EXO) or treated with $2 \mathrm{mmol} / \mathrm{L}$ (EXO $2 \mathrm{mmol} / \mathrm{L}$ ) or $5 \mathrm{mmol} /$ $L(E X 05 \mathrm{mmol} / \mathrm{L})$. Exosome treatment induces an enhanced cell motility in HCT116 (A) and Rat-1 (B) cell lines. Arrows indicate the wounding point.

undifferentiated HT29 cells, but in this case, the highest effect was observed with exosomes isolated by nondifferentiated cells (Figure 5B).

These findings were confirmed for both cell lines by monitoring cell proliferation in real time for 48 hours using the ECIS system (Figure 5).

We then tested the effects of different doses of exosomes and found that cell proliferation increased in a dosedependent manner $(1,2$, and $4 \mu \mathrm{g})$ in HCT116 cells exposed to exosomes, as assessed by ECIS assay (Figure 6A).

An important issue in the exosome field is whether and how exosomes are eventually internalized by recipient cells. ${ }^{24}$ Proteins expressed on the membranes of exosomes might be important in mediating their targeting and uptaking by recipient cells. Thus, to evaluate the importance of surface proteins in the observed phenomena, we treated the exosomes with proteinase $\mathrm{K}$ and found that treatment halted the increase in cell proliferation induced by exosomes isolated from 48-hour conditioned medium of HT29 untreated cells in both Rat-1 and HCT116 cells, thus confirming the key role of surface proteins in the observed effects on recipient cells (Figure 6, B and C).

Incubation with exosomes also induced an enhanced cell motility in both HCT116 and Rat-1 cells, with the effect increasing with exosomes released by differentiated cells, as assessed by scratch test with ECIS (Figure 7). This effect was prevented when exosomes were treated with proteinase $\mathrm{K}$ (Figure 8), thus further confirming the role of surface proteins in mediating exosome-induced effects on recipient cells.

To further evaluate how the exosome-recipient cell interaction could influence specific aspects of the cell migratory behavior, such as velocity, we used single-cell tracking of live cells and time-lapse confocal microscopy to evaluate cell movements. Representative trajectory plots of HCT116 cells exposed for 24 hours to exosomes isolated from undifferentiated and differentiated HT29 cells are reported in Figure 9A. Migration velocity was significantly increased in HCT116 incubated with HT29-derived exosomes compared to untreated cells, and this effect was enhanced with exosomes isolated from $\mathrm{NaBu}$-exposed, differentiated cells (Figure 9B). In addition, colony formation efficiency and soft agar colony formation assay indicated that both anchorage-dependent and anchorageindependent growth of HCT116 colon cancer cells were stimulated by HT29-derived exosomes compared to control untreated cells. Both effects were more evident using exosomes isolated from $\mathrm{NaBu}$-exposed, differentiated cells compared to exosomes isolated from control cultures of HT29 cells (Figure 10).

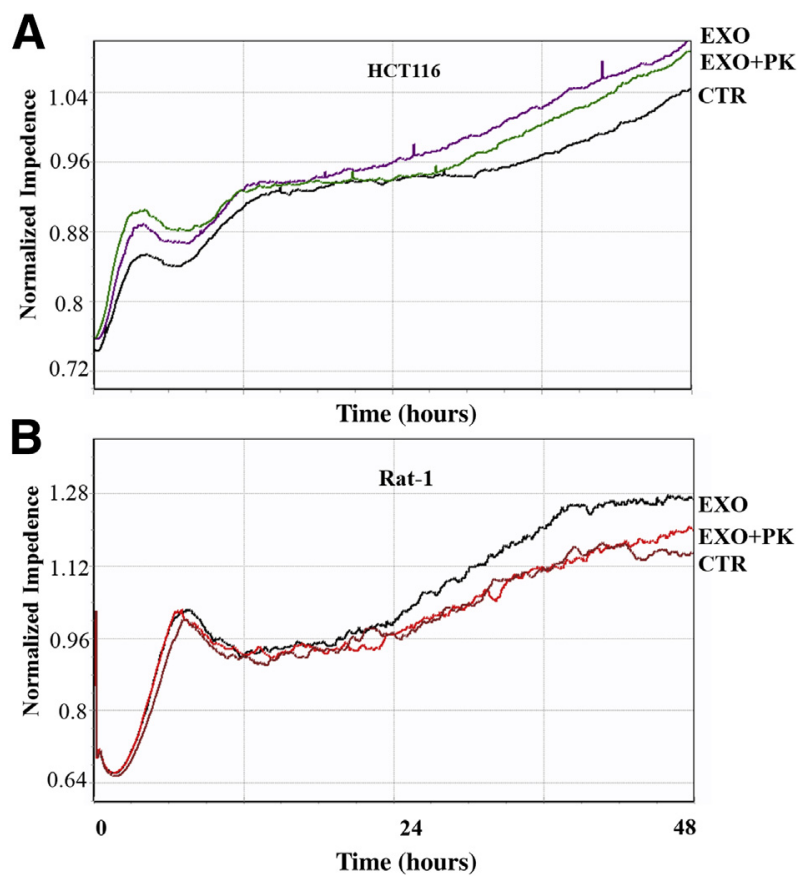

Figure 8 Exosome-induced increase in cell motility depends on surface proteins. HCT116 (A) and Rat-1 (B) cells were seeded in a confluent manner in electric cell-substrate impedance sensing arrays and the next day were exposed to a current pulse of $40-\mathrm{kHz}$ frequency for a duration of 30 seconds to perform the wound. The cells were then treated with $1 \mu \mathrm{g}$ of exosomes (EX0) pretreated with $5 \mu \mathrm{L}$ of $100 \mu \mathrm{g} / \mathrm{mL}$ of proteinase $\mathrm{K}$ (PK) before the incubation with cells and impedance was then monitored for the subsequent 48 hours compared to untreated cells. The treatment of exosomes with PK attenuates the increased cell motility induced by untreated exosomes. CTR, control. 
A

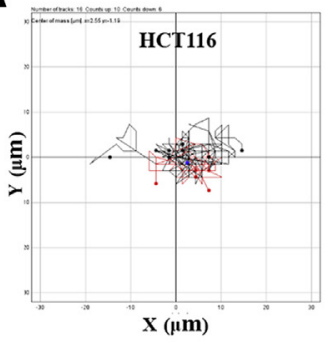

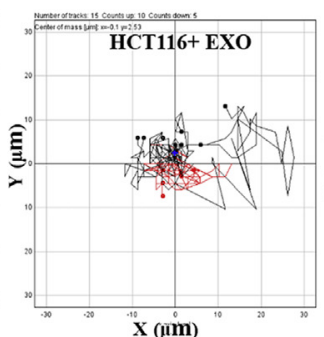

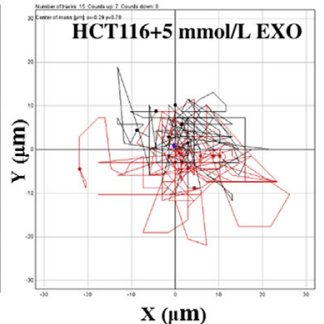

$\mathbf{X}(\mu \mathbf{m})$
B



Figure 9 HT29-derived exosomes increase cell velocity and movements in HCT116 cells. A: Representative trajectory plots evaluated in HCT116 and HCT116 cells treated with exosomes released by HT29 untreated (EXO) or treated with $5 \mathrm{mmol} / \mathrm{L} \mathrm{NaBu}(5 \mathrm{mmol} / \mathrm{L} \mathrm{EXO})$. Cells were allowed to grow to $30 \%$ to $40 \%$ confluence in complete medium in 35-mm glass-bottom Petri dishes and were incubated in medium in either the presence or absence of EX0 or $5 \mathrm{mmol} / \mathrm{L}$ EXO $(1 \mu \mathrm{g})$ for 24 hours. Then, the cells were labeled with Cell-Tracker (Laurdan) and cells were tracked over a time period of 45 minutes. The starting point of each cell trajectory is plotted at the center of the graph. B: The data shown represent the migration speed of HCT116 induced by the interaction with exosomes (EX0, $5 \mathrm{mmol} / \mathrm{L}$ EXO) compared to untreated cells (CTR). Data are expressed as means \pm SEM (B). ${ }^{*} P<0.05$ versus control and HCT116+EX0.

\section{HT29-Derived Exosomes Elicit Tyrosine} Phosphorylation of Cytoplasmic Proteins and Increase Src and ERK Phosphorylation

On the basis of the above findings, we set out to explore potential signaling mechanisms involved in the exosomeinduced effects on recipient cells. We used an immunoblot analysis of phosphorylated tyrosine (p-Tyr) to detect changes in the phosphorylation state of intracellular proteins induced by the incubation with exosomes. We observed an overall increase in the level of tyrosine phosphorylation in the HCT116 cells treated with HT29-derived exosomes, suggesting that they might activate intracellular signaling pathways by ligand-receptor interactions (Figure 11A). We then specifically analyzed the expression of Src and ERK proteins in exosome-treated cells and found that an increased phosphorylation of both proteins occurred in HCT116 cells treated with exosomes released by differentiated HT29 cells (Figure 11B). No changes were observed in the total expression level of both proteins as well as of the CD133 molecule. Interestingly, exosome pretreatment with proteinase $\mathrm{K}$ halted the increased phosphorylation of Src and ERK induced by HT29-derived exosomes in HCT116 cells (Figure 11C).

It is well known that pSrc plays an important role in epithelial-to-mesenchymal transition (EMT) and in cytoskeletal dynamics of colon cancer cells. ${ }^{25}$ Thus, we verified whether genes related to these processes might also be

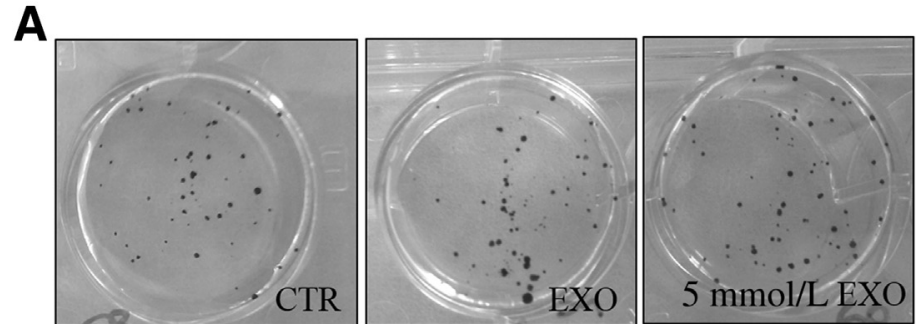

B

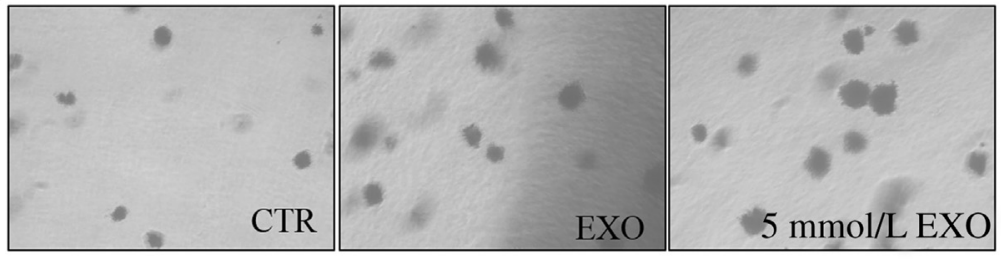



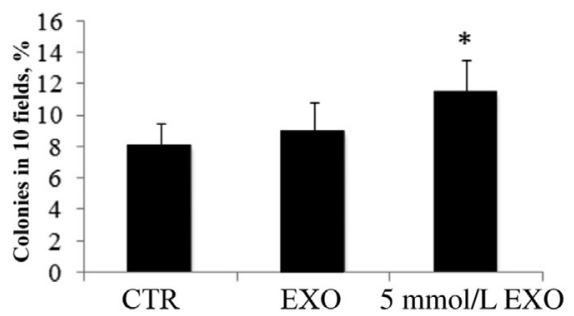

Figure 10 HT29-derived exosomes increase both anchorage-dependent and anchorage-independent growth of HCT116 colon cancer cells. Colony formation efficiency (A) and soft agar colony assay (B) (representative images from the assays are shown). A: Five hundred HCT116 colon cancer cells were plated onto $100-\mathrm{mm}$ dishes and every 2 days up to 2 weeks the medium was replaced with fresh medium containing $1 \mu \mathrm{g}$ of exosomes released by HT29 untreated (EX0) or treated with $1 \mu \mathrm{g}$ of $5 \mathrm{mmol} / \mathrm{L} \mathrm{NaBu}$ for 48 hours ( $5 \mathrm{mmol} / \mathrm{L} \mathrm{EX0).} \mathrm{After} 2$ weeks, the colonies were fixed, stained with crystal violet, and counted. B: HCT116 cells were suspended in $0.4 \%$ agar mixed with serum-free medium containing $1 \mu \mathrm{g}$ of EX0 or $5 \mathrm{mmol} / \mathrm{L}$ EXO and overlaid on $0.6 \%$ agar in 6 -well plates $\left(2 \times 10^{4}\right.$ cells/well). After 3 weeks, colonies were counted and imaged. Data are expressed as means \pm SEM. Statistical plots were conducted from 10 randomly selected fields. ${ }^{*} P<0.05$ versus control. Original magnification, $\times 20$ (B). CTR, untreated control. 


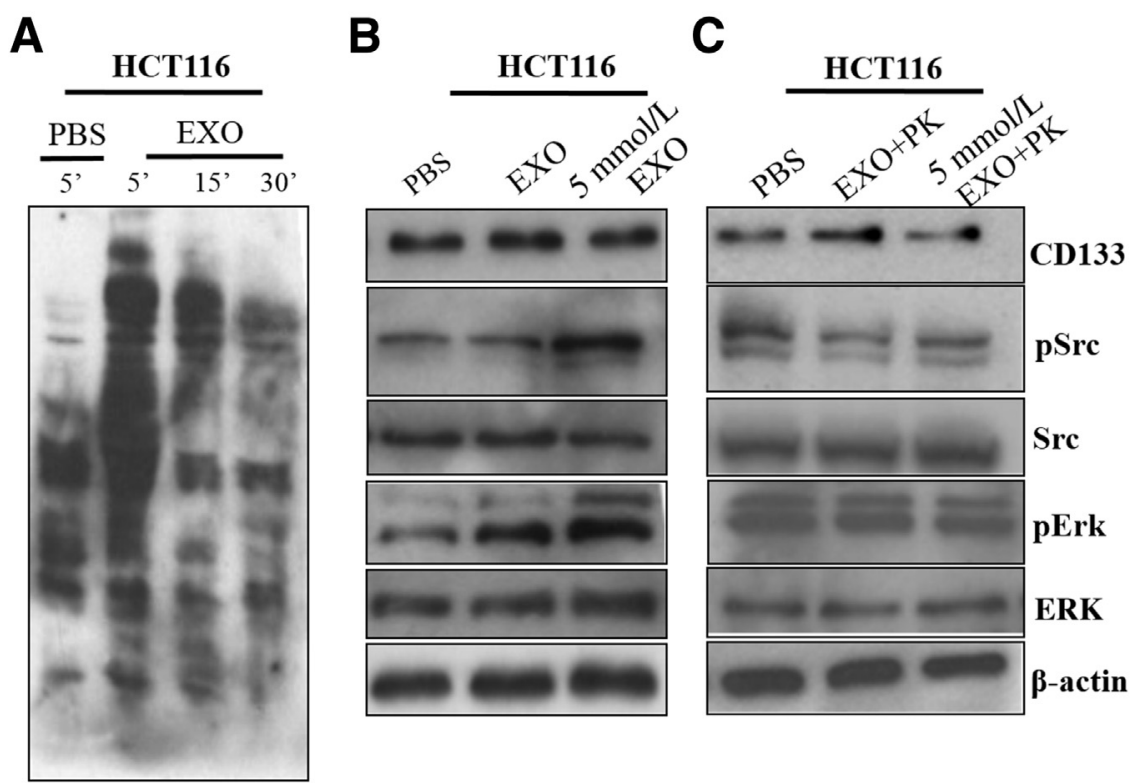

Figure 11 HT29-derived exosomes increase the phosphorylation state of intracellular proteins in HCT116 cells. A: Western blot analysis of phosphorylated tyrosine in HCT116 cells treated for 5 minutes, 15 minutes, and 30 minutes with 1 $\mu \mathrm{g}$ of HT29-derived exosomes (EXO) compared with vehicle-treated [phosphate-buffered saline (PBS)] cells. B: Western blot analysis of the indicated proteins in HCT116 treated for 48 hours with $1 \mu \mathrm{g}$ of exosomes released by HT29 untreated (EXO) or treated with $5 \mathrm{mmol} / \mathrm{L} \mathrm{NaBu}$ for 48 hours (EXO 5 $\mathrm{mmol} / \mathrm{L})$ compared with PBS-treated control cells. C: Same experiment as described in B using exosomes pretreated with proteinase K (PK). ERK, extracellular signal regulated kinase. affected by exosome treatment. We found that exosomes released by both undifferentiated and differentiated HT29 cells were able to induce an increase of mesenchymal features in HCT116 cells. Indeed, exosome-exposed HCT116 expressed increased levels of vimentin and the transcription factor Zeb1, together with a reduction of E-cadherin expression (Figure 12A). Furthermore, a modulation of RhoGTPase expression (RhoA, Rac1, Cdc42), involved in cell polarity and migration, was also observed in the same cells exposed to HT29-released exosomes (Figure 12B).

mRNA expression levels of the potential inducers of EMT, such as vascular endothelial growth factor and transforming growth factor- $\beta$, also increased in the same cells, whereas CD133 and Cav-1 expression levels were not affected (Figure 12C).

To evaluate whether HT29-derived exosomes might exert the same effects on fibroblasts, we then treated Rat-1 fibroblasts with exosomes released by both undifferentiated and differentiated HT29 cells. HT29-released exosomes triggered $\alpha$-smooth muscle actin and vimentin expression in fibroblasts; however, they did not affect RhoA and CdC42 expression levels (Figure 13). We were not able to detect the expression of E-cadherin, transforming growth factor- $\beta$, and Rac-1 genes in Rat-1 cells (data not shown).

\section{HT29 Differentiating Cells Release Exosomes Enriched in Specific miRNAs}

Exosomes carry a broad number of cargo, including miRNAs. ${ }^{26}$ Specific miRNAs, such as miR-24, miR-27a, and miR-26a, have been previously reported to be associated with EMT in colorectal cancer cells. ${ }^{27}$ Thus, we evaluated expression levels of these miRNAs in HT29-derived exosomes and whether they changed on $\mathrm{NaBu}$-induced differentiation. Expression levels of miR-24, miR-27a, and miR-26a increased in exosomes after $\mathrm{NaBu}$-induced differentiation (Figure 14A). Increased expression of miR-24 and miR-27a was also detected in HCT116 after incubation of 48 hours with exosomes released by both undifferentiated and differentiated HT29 cells (Figure 14B).

\section{Discussion}

This study evaluated whether changes occur in exosomes released by colorectal cancer (CRC) cells on differentiation, using as a cell model the $\mathrm{NaBu}$-induced differentiation of HT29 and Caco-2 human CRC cell lines. ${ }^{14}$ Our findings suggest that the differentiation status of CRC cells quantitatively and qualitatively affects exosome release. Thus, because cancer cells likely use exosomes to communicate with their environment, they also suggest that the ability of cancer cells to modulate the surrounding microenvironment changes on differentiation.

It has been reported that cancer cells use exosomes to get rid of stem cell components when they are induced to differentiate. ${ }^{11,12}$ We showed that the reduction of the colon cancer stem cell marker CD133 in HT29 cells induced to differentiate after $\mathrm{NaBu}$ administration led to an increased release of CD133-enriched exosomes. This effect was specific because it was not observed for other proteins, such as caveolin-1, a scaffolding protein that is concentrated in lipid raft and most abundantly expressed in terminally differentiated cells ${ }^{28,29}$; it increased in $\mathrm{NaBu}$-differentiated cells, whereas its expression decreased in exosomes (Figure 2). Exosomes are formed intracellularly via endocytic invagination and are released into a multivesicular body maturation. $^{30}$ Our findings demonstrated that blocking multivesicular body maturation using ammonium chloride 
A
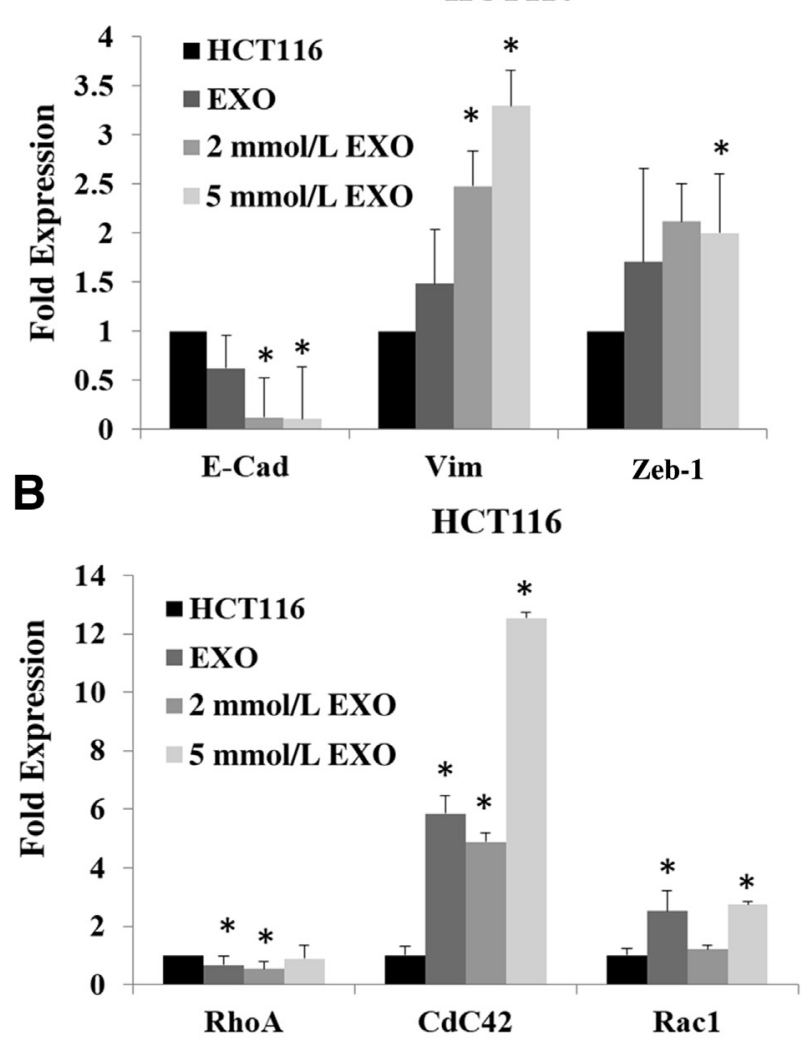

C

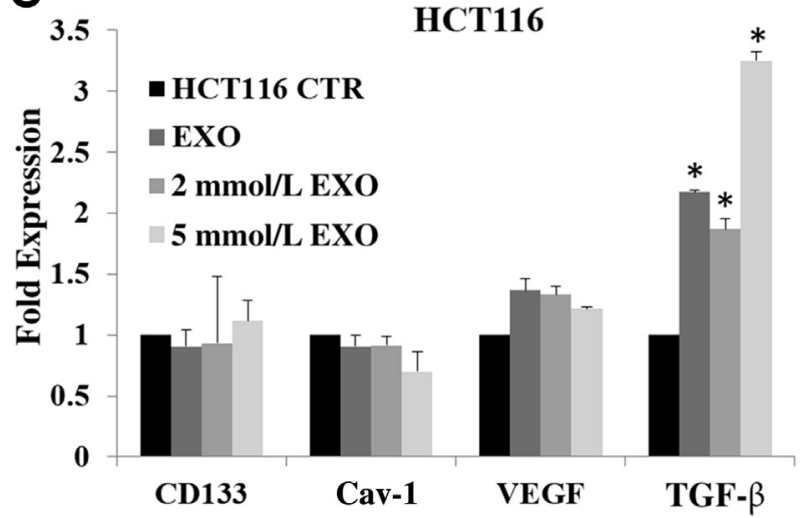

Figure 12 HT29-derived exosomes increase EMT features in HCT116 cells. Quantitative real-time PCR analysis of the indicated genes in HCT116 treated for 48 hours with $1 \mu \mathrm{g}$ of exosomes released by HT29 untreated (EXO) or treated with 2 ( $2 \mathrm{mmol} / \mathrm{L}$ EXO) or $5(5 \mathrm{mmol} / \mathrm{L}$ EXO) $\mathrm{mmol} / \mathrm{L} \mathrm{NaBu}$ for 48 hours compared with untreated control cells (CTR). A and B: Markers of EMT [vimentin (Vim), Zeb-1, transforming growth factor- $\beta$ (TGF- $\beta$ ), and vascular endothelial growth factor (VEGF)] and RhoGTPase genes are increased in exosome-treated HCT116. C: However, CD133 and Cav-1 expression does not change. Data are expressed as means \pm SEM. ${ }^{*} P<0.05$ versus CTR cells.

halted CD133 decrease as well as NaBu-induced differentiation of both HT29 and Caco-2 cells (Figures 2 and 3). These data suggest that the release of CD133-enriched exosomes might be necessary for the differentiation of HT29 CRC cells.

Exosomes are used by both normal and cancer cells to communicate with recipient cells in the surrounding environment. Effects of exosomes on recipient cells seem to be dependent on the originating cell type as well as on their cargo. ${ }^{23}$ We therefore hypothesized that exosomes released on $\mathrm{NaBu}$-induced differentiation could carry different molecules (ie, stem cell components) compared to exosomes released by undifferentiated cells with a potential ability to differentially affect the behavior of both normal and tumor recipient cells.

Indeed, exosomes released by both undifferentiated and differentiated HT29 cells were able to affect the behavior of both the HCT116 colon cancer cells and the Rat-1 normal fibroblasts. In HCT116 cells, HT29-derived exosomes induced an increased cell proliferation and motility as well as an increased anchorage-independent growth, an important feature strictly related to in vivo tumorigenicity. Similar effects on cell growth and motility were also observed in Rat-1 cells (Figures 5, 6, 7, 8, 9, and 10). These results are consistent with data in the literature suggesting the involvement of exosomes in cell motility. ${ }^{31,32}$

Interestingly, these exosome-induced effects on recipient cells were more evident with exosomes released by differentiated cells compared to those released by undifferentiated HT29 cells. This phenomenon depends on the content of exosomes produced by differentiated cells, which likely carry more stem cell components (ie, CD133) and signaling molecules involved in cell growth and motility, which differentiating cells want to get rid of. Indeed, we previously reported that CD133 cellular levels decrease in HT29 undergoing $\mathrm{NaBu}$-induced differentiation, ${ }^{14}$ and we now demonstrated that this phenomenon is associated with the release of CD133enriched exosomes. Rappa et $\mathrm{al}^{13}$ have shown that CD133expressing exosomes isolated from melanoma and colon carcinoma cells were able to affect the invasiveness and other

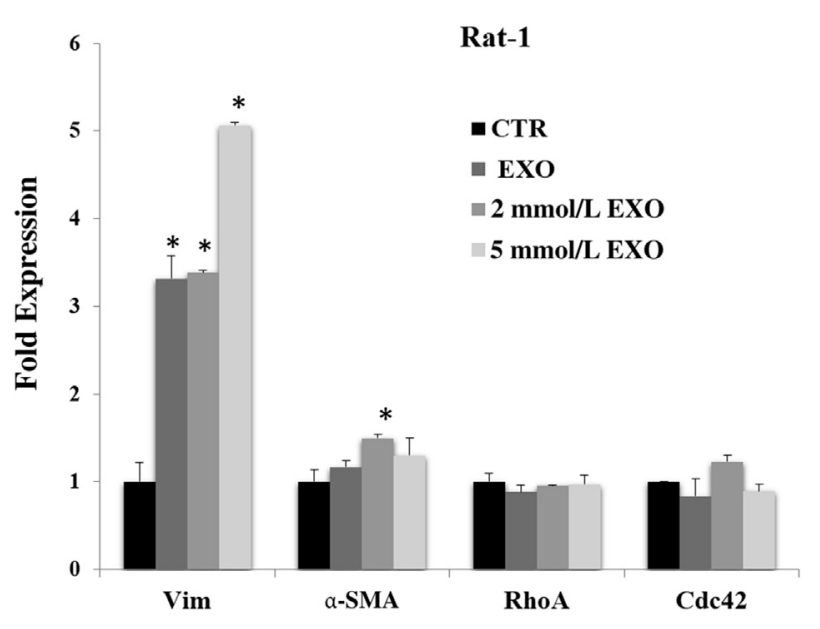

Figure 13 HT29-derived exosomes increase expression of mesenchymal markers in normal rodent fibroblasts. Quantitative real-time PCR of the indicated genes in Rat- 1 fibroblasts treated for 48 hours with $1 \mu \mathrm{g}$ of exosome released by HT29 untreated (EXO) or treated with 2 ( $2 \mathrm{mmol} / \mathrm{L} \mathrm{EXO)}$ or 5 $(5 \mathrm{mmol} / \mathrm{L} \mathrm{EXO}) \mathrm{mmol} / \mathrm{L} \mathrm{NaBu}$ for 48 hours compared with untreated control cells (CTR). Data are expressed as means \pm SEM. ${ }^{*} P<0.05$ versus control cells. $\alpha$-SMA, $\alpha$-smooth muscle actin; Vim, vimentin. 


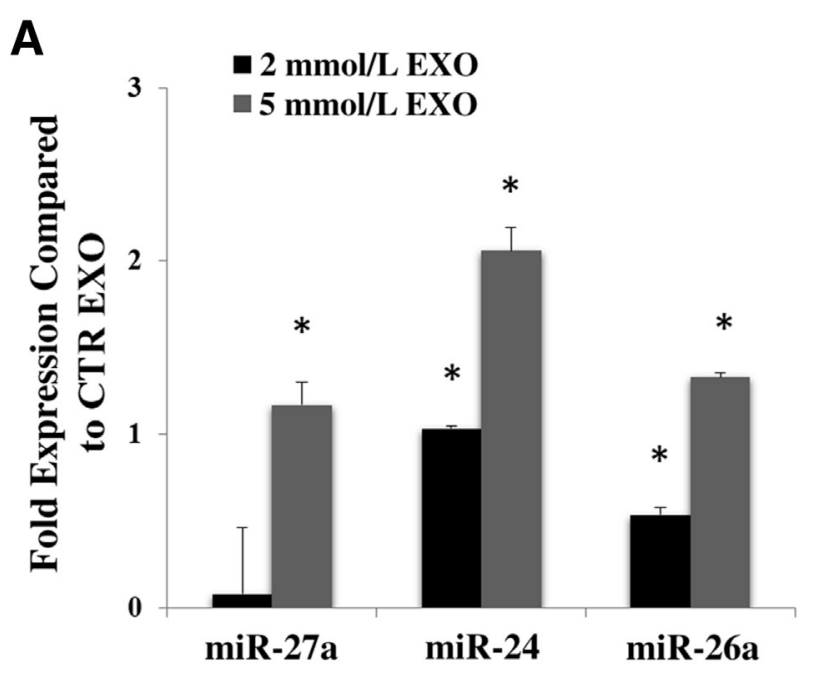

B

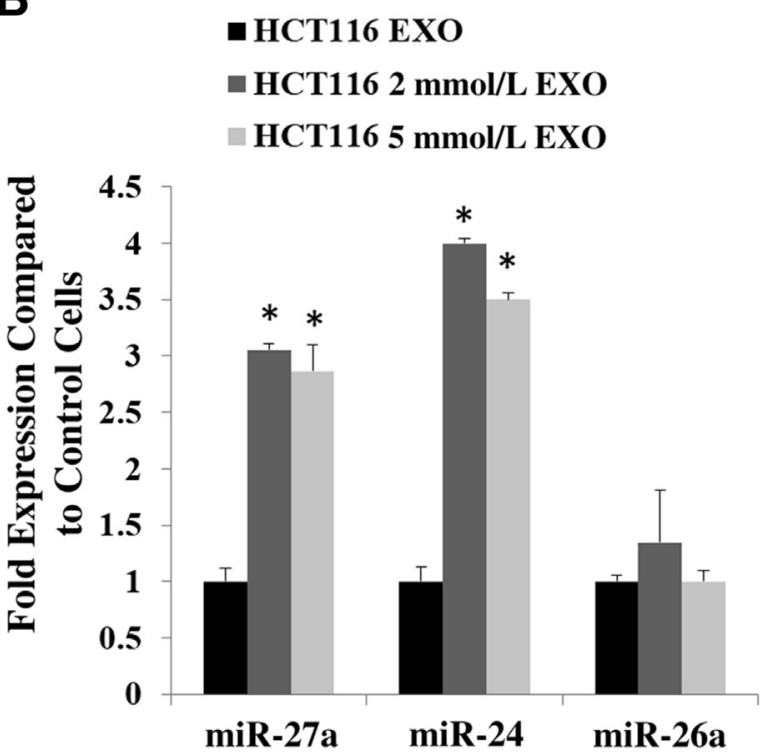

Figure 14 Expression of specific miRNAs increases in HT29-derived exosomes on differentiation. A: Quantitative real-time PCR of the indicated miRNAs in exosomes released by HT29 cells treated with $2(2 \mathrm{mmol} / \mathrm{L}$ EXO) or 5 ( $5 \mathrm{mmol} / \mathrm{L} \mathrm{EXO)} \mathrm{mmol} / \mathrm{L} \mathrm{NaBu}$ for 48 hours. Data are expressed as fold increase compared with levels in exosomes released by HT29 untreated control cells (CTR EXO). B: Quantitative real-time PCR of the indicated miRNAs in HCT116 cultures incubated for 48 hours with $1 \mu \mathrm{g}$ of exosomes released by HT29 cells untreated (EXO) or treated for 48 hours with $2(2 \mathrm{mmol} / \mathrm{L} \mathrm{EXO})$ or $5(5 \mathrm{mmol} / \mathrm{L}$ EXO) $\mathrm{mmol} / \mathrm{L} \mathrm{NaBu}$. Data are expressed as means \pm SEM. Data are expressed as fold increase compared with levels in control HCT116 cells. ${ }^{*} P<0.05$ versus CTR.

features of melanoma and bone marrow-derived stromal cells, thus suggesting that specific populations of cancer exosomes might contain multiple determinants of the cells from which they are derived able to affect the behavior of recipient cells. This observation is consistent with our finding that exosomes isolated by $\mathrm{NaBu}$-differentiated cells reduced $\mathrm{NaBu}$-induced differentiation of recipient HT29 cells and can explain the effects observed in HCT116 and Rat-1 after treatment with HT29-derived exosomes.
Molecular changes observed in recipient cells exposed to exosomes could be also because of determinants of the cells of origin. We observed an increase in the phosphorylation state of intracellular proteins and, specifically, of Src and ERK molecules in exosome-exposed HCT116 cells. It is not clear how exosomes can induce such effects in recipient cells. However, they were prevented after pretreatment of exosomes with proteinase $\mathrm{K}$, thus suggesting an important role of surface proteins in mediating exosome-induced effects. Treatment of exosomes with proteinase $\mathrm{K}$ was shown to decrease exosome uptake in ovarian cancer, indicating that surface proteins of exosomes are involved in their internalization. ${ }^{24}$ Thus, surface proteins, likely interacting with membrane proteins on target cells, might be pivotal either to mediate entry of exosomes into recipient cells or to stimulate receptor proteins able to activate intracellular signaling pathways. Studies are ongoing to verify these possibilities, although we believe that different surface proteins on exosomes might be involved in either one or the other mechanism.

We have shown that HCT116 cells treated with exosomes displayed an increased expression of EMT markers vimentin and Zeb-1 and a reduction of the epithelial marker E-cadherin, associated with an increased expression of the CDC42 gene. During the EMT process, the epithelial cells acquire fibroblast-like properties and exhibit reduced cellcell adhesion and increased motility, which facilitates the escape of tumor cells from primary tumors. ${ }^{32,33}$ The Rho family of GTPases has the ability to regulate the cytoskeletal dynamics, cell adhesion, and migration through the loss of epithelial cell-cell contacts, and CDC42 can stimulate cell migration and contribute to cancer cell invasion. ${ }^{34,35} \mathrm{Src}$ has been reported to be involved in EMT and cytoskeleton dynamics. ${ }^{36}$ Thus, the effects on cell motility and EMT observed in exosome-treated cells might be a consequence of Src activation. Moreover, several studies have shown that in cancer cells, CD133 facilitates EMT through interaction with the Src-ERK pathway. ${ }^{37,38}$ Thus, exosomes enriched in CD133 could trigger EMT through the activation of Src and ERK phosphorylation activating intracellular signaling pathways by ligand-receptor interaction or through the release of signaling molecules after exosome uptake by recipient cells. However, it is of interest that exosomes released by undifferentiated HT29 cells were also able to modulate EMT-related genes in recipient cells, thus further supporting the hypothesis that cancer cells might induce EMT of surrounding cells through exosome release. Further studies are ongoing to test this hypothesis.

A wide variety of molecules are contained in exosomes: miRNAs, DNA, proteins, and mRNA. ${ }^{23}$ miRNAs have attracted the most attention because of their regulatory roles in gene expression; recent findings showed that the proportion of miRNA is higher in exosomes than in their parent cells. ${ }^{39}$ Researchers have shown that exosomal miRNAs appear to mirror pathological changes of CRC cells, whereas others have suggested that a subset of miRNAs 


\section{Extracellular environment}



Figure 15 Proposed model for exosome paracrine control of cell proliferation and motility. When exposed to exosomes' cargoes, cells increase the phosphorylation of key molecules involved in adhesion, motility, and proliferation pathways (Src and ERK), thus activating intracellular signaling pathways, which might depend on ligand-receptor interaction without internalization or require cell uptake of exosomes by membrane fusion. EMT, epithelial mesenchymal transition. preferentially enter into exosomes. ${ }^{40,41}$ We investigated the expression of miR-24, miR-7a, and miR-26a on the basis of literature data suggesting the involvement of these miRNAs in cell migration and EMT. ${ }^{27}$ Moreover, Papadimitriou et $\mathrm{al}^{42}$ showed that miR-24 regulates the EMT program in response to transforming growth factor- $\beta$ in breast cancer cells, and miR-24 and miR-26a expression levels were shown to be higher in colon cancer than in normal colon tissues. ${ }^{27}$ Finally, miR-26a and miR-27a were reported to be abundant in extracellular vesicles of glioblastoma cells. ${ }^{43}$ We showed that miR-24, miR-27a, and miR-26a increase in exosomes released from differentiated HT29 cells, whereas their cellular levels decrease on differentiation. Moreover, we observed a statistically significant increase of miR-24 and miR-27a in HCT116 exposed to exosomes released from differentiated cells. Overall, our findings suggest that during NaBu-induced differentiation of HT29, cell expression levels of a subset of miRNAs might decrease in differentiated cells while increasing in released exosomes, which could, then, transfer these miRNAs to recipient cells (Figure 14).

These findings further support the reported evidence suggesting the ability of cancer cells to modulate the behavior of both normal and tumor surrounding cells. ${ }^{44} \mathrm{We}$ also showed an increase of markers of myofibroblast differentiation (vimentin and $\alpha$-smooth muscle actin) in Rat1 fibroblasts treated with HT29-derived exosomes. Differentiation in myofibroblasts has been associated with increased cell migration. ${ }^{45,46}$ Thus, this finding could explain the increased motility observed in exosome-treated Rat-1 fibroblasts. It is also consistent with data showing an abnormally increased presence of myofibroblastic cells capable of supporting tumor growth in the interstitial stroma of carcinomas. ${ }^{46}$ In agreement with our results, Webber et $\mathrm{al}^{44}$ showed that prostate cancer exosomes could trigger fibroblasts to myofibroblast differentiation and that cancerderived exosomes are a component of tumor to stromal cell communication required for generating a supporting stromal phenotype. ${ }^{47,48}$ Overall, these findings give support to the mounting evidence suggesting that exosome-related molecular signals can induce profound changes within the microenvironment of a developing tumor.

The different behavior of Rat- 1 cells (a reduced effect on cell proliferation after incubation with exosomes isolated from HT29 differentiated cells compared to exosomes released from undifferentiated cells) compared to HCT116 cells could be attributed to the higher expression of miR-26a in exosomes isolated from differentiated cells. Indeed, $\mathrm{Li}$ et $\mathrm{al}^{49}$ have shown that miR-26a reduced the proliferation rate of human fetal lung fibroblasts, and this evidence could 
be linked to the minor effects of exosomes isolated from differentiated HT29 cells on Rat-1 cell proliferation.

The proneoplastic or antineoplastic effect of $\mathrm{NaBu}$ is still controversial. In fact, it stimulates the apoptosis and differentiation of cancer cells but, on the other hand, could trigger cell proliferation and motility. ${ }^{50}$ Mechanisms that enable tumor cells to escape the differentiating effects of $\mathrm{NaBu}$ are not well understood: Gibson et $\mathrm{a}^{51}$ suggested that normal cells are involved in oxidation of butyrate, leading to low intracellular levels, and that they could produce factors inducing resistance, whereas Sengupta et $\mathrm{al}^{50}$ hypothesized that the response of cells to butyrate may depend on the cells' state of activation independently of $\beta$-oxidation. Finally, it has also been suggested that butyrate can act as a stimulator of growth or an inducer of apoptosis in human colonic epithelial cells, depending on the presence of alternative energy sources, such as glucose. ${ }^{52}$ We hypothesized that this paradox effect could be explained taking into account the release by $\mathrm{NaBu}$-exposed cells of exosomes carrying stem cell components, which could induce a change in the behavior of cells in the tumor microenvironment. Our hypothesis is that the cargoes of exosomes, such as miRNA, mRNA, and transmembrane protein, after a stimulus of differentiation, could be released as components that are no longer necessary for the differentiating cells but could be able to affect the behavior of cells in the tumor microenvironment. Our findings suggest that exosomes' cargoes could increase the phosphorylation of key molecules involved in adhesion, motility, proliferation, and EMT pathway (Src and ERK), which might promote migration and proliferation of tumor and stromal cells, thus representing a mechanism allowing surrounding tumor cells to escape the effects of $\mathrm{NaBu}$ (Figure 15). If this hypothesis is proved to be true, the findings of this study could suggest that blocking the release of exosomes in addition to the administration of $\mathrm{NaBu}$ could be a valid therapeutic option to prevent failure of $\mathrm{NaBu}$-based therapies ${ }^{50}$ for the benefit of CRC patients.

\section{References}

1. Torre LA, Bray F, Siegel RL, Ferlay J, Lortet-Tieulent J, Jemal A Global cancer statistics, 2012. CA Cancer J Clin 2015, 65:87-108

2. Li Y, Wicha MS, Schwartz SJ, Sun D: Implications of cancer stem cell theory for cancer chemoprevention by natural dietary compounds. J Nutr Biochem 2011, 22:799-806

3. Louis P, Hold GL, Flint HJ: The gut microbiota, bacterial metabolites and colorectal cancer. Nat Rev Microbiol 2014, 12:661-672

4. Basson MD, Emenaker NJ, Hong F: Differential modulation of human (Caco-2) colon cancer cell line phenotype by short chain fatty acids. Proc Soc Exp Biol Med 1998, 217:476-483

5. Barnard JA, Warwick G: Butyrate rapidly induces growth inhibition and differentiation in HT-29 cells. Cell Growth Differ 1993, 4:495-501

6. Heerdt BG, Houston MA, Augenlicht LH: Potentiation by specific short-chain fatty acids of differentiation and apoptosis in human colonic carcinoma cell lines. Cancer Res 1994, 54:3288-3293

7. Weigmann A, Corbeil D, Hellwig A, Huttner WB: Prominin, a novel microvilli-specific polytopic membrane protein of the apical surface of epithelial cells, is targeted to plasmalemmal protrusions of non-epithelial cells. Proc Natl Acad Sci U S A 1997, 94: $12425-12430$

8. Ricci-Vitiani L, Lombardi DG, Pilozzi E, Biffoni M, Todaro M, Peschle C, De Maria R: Identification and expansion of human coloncancer-initiating cells. Nature 2007, 445:111-115

9. O'Brien CA, Pollett A, Gallinger S, Dick JE: A human colon cancer cell capable of initiating tumour growth in immunodeficient mice. Nature 2007, 445:106-110

10. Fanali C, Lucchetti D, Farina M, Corbi M, Cufino V, Cittadini A, Sgambato A: Cancer stem cells in colorectal cancer from pathogenesis to therapy: controversies and perspectives. World J Gastroenterol 2014, 20:923-942

11. Marzesco AM, Janich $\mathrm{P}$, Wilsch-Bräuninger $\mathrm{M}$, Dubreuil V, Langenfeld K, Corbeil D, Huttner WB: Release of extracellular membrane particles carrying the stem cell marker prominin-1 (CD133) from neural progenitors and other epithelial cells. J Cell Sci 2005, 118:2849-2858

12. Bauer N, Wilsch-Bräuninger $\mathrm{M}$, Karbanová J, Fonseca AV, Strauss D, Freund D, Thiele C, Huttner WB, Bornhäuser M, Corbeil D: Haematopoietic stem cell differentiation promotes the release of prominin-1/CD133-containing membrane vesicles: a role of the endocytic-exocytic pathway. EMBO Mol Med 2011, 3:398-409

13. Rappa G, Mercapide J, Anzanello F, Pope RM, Lorico A: Biochemical and biological characterization of exosomes containing prominin-1/CD133. Mol Cancer 2013, 12:62

14. Sgambato A, Puglisi MA, Errico F, Rafanelli F, Boninsegna A, Rettino A, Genovese G, Coco C, Gasbarrini A, Cittadini A: Posttranslational modulation of CD133 expression during sodium butyrate-induced differentiation of HT29 human colon cancer cells: implications for its detection. J Cell Physiol 2010, 224:234-241

15. Théry C, Amigorena S, Raposo G, Clayton A: Isolation and characterization of exosomes from cell culture supernatants and biological fluids. Curr Protoc Cell Biol 2006, Chapter 3:Unit 3.22

16. Palmieri V, Lucchetti D, Gatto I, Maiorana A, Marcantoni M, Maulucci G, Papi M, Pola R, De Spirito M, Sgambato A: Dynamic light scattering for the characterization and counting of extracellular vesicles: a powerful non invasive tool. J Nanopart Res 2014, 16:2583-2592

17. Sgambato A, Camerini A, Pani G, Cangiano R, Faraglia B, Bianchino G, De Bari B, Galeotti T, Cittadini A: Increased expression of cyclin $\mathrm{E}$ is associated with an increased resistance to doxorubicin in rat fibroblasts. Br J Cancer 2003, 88:1956-1962

18. Sgambato A, De Paola B, Migaldi M, Di Salvatore M, Rettino A, Faraglia B, Boninsegna A, Maiorana A, Cittadini A: Dystroglycan expression is reduced during prostate tumorigenesis and is regulated by androgens in prostate cancer cells. J Cell Physiol 2007, 213: $528-539$

19. Sgambato A, Camerini A, Faraglia B, Pavoni E, Montanari M, Spada D, Losasso C, Brancaccio A, Cittadini A: Increased expression of dystroglycan inhibits the growth and tumorigenicity of human mammary epithelial cells. Cancer Biol Ther 2004, 3: 967-975

20. Palmieri V, Lucchetti D, Maiorana A, Papi M, Maulucci G, Calapà F, Ciasca G, Giordano R, Sgambato A, De Spirito M: Mechanical and structural comparison between primary tumor and lymph node metastasis cells in colorectal cancer. Soft Matter 2015, 11:5719-5726

21. Angelucci C, Maulucci G, Colabianchi A, Iacopino F, D’Alessio A, Maiorana A, Palmieri V, Papi M, De Spirito M, Di Leone A, Masetti R, Sica G: Stearoyl-CoA desaturase 1 and paracrine diffusible signals have a major role in the promotion of breast cancer cell migration induced by cancer-associated fibroblasts. $\mathrm{Br} \mathrm{J}$ Cancer 2015 , 112:1675-1686

22. Gross JC, Chaudhary V, Bartscherer K, Boutros M: Active Wnt proteins are secreted on exosomes. Nat Cell Biol 2012, 14 1036-1045

23. Braicu C, Tomuleasa C, Monroig P, Cucuianu A, BerindanNeagoe I, Calin GA: Exosomes as divine messengers: are they the 
Hermes of modern molecular oncology? Cell Death Differ 2015, 22:34-45

24. Escrevente C, Keller S, Altevogt P, Costa J: Interaction and uptake of exosomes by ovarian cancer cells. BMC Cancer 2011, 11:108

25. Avizienyte E, Brunton VG, Fincham VJ, Frame MC: The SRCinduced mesenchymal state in late-stage colon cancer cells. Cells Tissues Organs 2005, 179:73-80

26. Volinia S, Calin GA, Liu CG, Ambs S, Cimmino A, Petrocca F, Visone R, Iorio M, Roldo C, Ferracin M, Prueitt RL, Yanaihara N, Lanza G, Scarpa A, Vecchione A, Negrini M, Harris CC, Croce CMA: microRNA expression signature of human solid tumors defines cancer gene targets. Proc Natl Acad Sci U S A 2006, 103: $2257-2261$

27. Thind A, Wilson C: Exosomal miRNAs as cancer biomarkers and therapeutic targets. J Extracell Vesicles 2016, 5:31292

28. Baker N, Zhang G, You Y, Tuan RS: Caveolin-1 regulates proliferation and osteogenic differentiation of human mesenchymal stem cells. J Cell Biochem 2012, 113:3773-3787

29. Dasgupta N, Kumar Thakur B, Ta A, Das S: Caveolin-1 is transcribed from a hypermethylated promoter to mediate colonocyte differentiation and apoptosis. Exp Cell Res 2015, 334:323-336

30. Urbanelli L, Magini A, Buratta S, Brozzi A, Sagini K, Polchi A, Tancini B, Emiliani C: Signaling pathways in exosomes biogenesis, secretion and fate. Genes (Basel) 2013, 4:152-170

31. Luga V, Zhang L, Viloria-Petit AM, Ogunjimi AA, Inanlou MR, Chiu E, Buchanan M, Hosein AN, Basik M, Wrana JL: Exosomes mediate stromal mobilization of autocrine Wnt-PCP signaling in breast cancer cell migration. Cell 2012, 151: $1542-1556$

32. Sung BH, Ketova T, Hoshino D, Zijlstra A, Weaver AM: Directional cell movement through tissues is controlled by exosome secretion. Nat Commun 2015, 6:7164

33. Mani SA, Guo W, Liao MJ, Eaton EN, Ayyanan A, Zhou AY, Brooks M, Reinhard F, Zhang CC, Shipitsin M, Campbell LL, Polyak K, Brisken C, Yang J, Weinberg RA: The epithelialmesenchymal transition generates cells with properties of stem cells. Cell 2008, 133:704-715

34. Huber MA, Kraut N, Beug H: Molecular requirements for epithelialmesenchymal transition during tumor progression. Curr Opin Cell Biol 2005, 17:548-558

35. Hanna S, El-Sibai M: Signaling networks of Rho GTPases in cell motility. Cell Signal 2013, 25:1955-1961

36. Vega FM, Ridley AJ: Rho GTPases in cancer cell biology. FEBS Lett 2008, 582:2093-2101

37. Su B, Gao L, Meng F, Guo LW, Rothschild J, Gelman IH: Adhesionmediated cytoskeletal remodeling is controlled by the direct scaffolding of Src from FAK complexes to lipid rafts by SSeCKS/AKAP12. Oncogene 2013, 32:2016-2026

38. Ding Q, Miyazaki Y, Tsukasa K, Matsubara S, Yoshimitsu M, Takao S: CD133 facilitates epithelial-mesenchymal transition through interaction with the ERK pathway in pancreatic cancer metastasis. Mol Cancer 2014, 13:15

39. Chen B, Liu Y, Jin X, Lu W, Liu J, Xia Z, Yuan Q, Zhao X, Xu N, Liang S: MicroRNA-26a regulates glucose metabolism by direct targeting PDHX in colorectal cancer cells. BMC Cancer 2014, 14 443

40. Goldie BJ, Dun MD, Lin M, Smith ND, Verrills NM, Cairns MJ: Activity-associated miRNA are packaged in Maplb-enriched exosomes released from depolarized neurons. Nucleic Acids Res 2014, 42:9195-9208

41. Ogata-Kawata H, Izumiya M, Kurioka D, Honma Y, Yamada Y, Furuta K, Gunji T, Ohta H, Okamoto H, Sonoda H, Watanabe M, Nakagama H, Yokota J, Kohno T, Tsuchiya N: Circulating exosomal microRNAs as biomarkers of colon cancer. PLoS One 2014, 9: e92921

42. Papadimitriou E, Vasilaki E, Vorvis C, Iliopoulos D, Moustakas A, Kardassis D, Stournaras C: Differential regulation of the two RhoAspecific GEF isoforms Net1/Net1A by TGF- $\beta$ and miR-24: role in epithelial-to-mesenchymal transition. Oncogene 2012, 31: 2862-2875

43. Skog J, Würdinger T, van Rijn S, Meijer DH, Gainche L, SenaEsteves M, Curry WT, Carter BS, Krichevsky AM, Breakefield XO: Glioblastoma microvesicles transport RNA and proteins that promote tumour growth and provide diagnostic biomarkers. Nat Cell Biol 2008, 10:1470-1476

44. Webber J, Steadman R, Mason MD, Tabi Z, Clayton A: Cancer exosomes trigger fibroblast to myofibroblast differentiation. Cancer Res 2010, 70:9621-9630

45. Carthy JM, Garmaroudi FS, Luo Z, McManus BM: Wnt3a induces myofibroblast differentiation by upregulating TGF- $\beta$ signaling through SMAD2 in a $\beta$-catenin-dependent manner. PLoS One 2011, 6:e19809

46. Zhang D, Wang Y, Shi Z, Liu J, Sun P, Hou X, Zhang J, Zhao S, Zhou BP, Mi J: Metabolic reprogramming of cancer-associated fibroblasts by IDH3 $\alpha$ downregulation. Cell Rep 2015, 10: $1335-1348$

47. Webber JP, Spary LK, Sanders AJ, Chowdhury R, Jiang WG, Steadman RWymant J, Jones AT, Kynaston H, Mason MD, Tabi Z, Clayton A: Differentiation of tumour-promoting stromal myofibroblasts by cancer exosomes. Oncogene 2015, 34:290-302

48. Chowdhury R, Webber JP, Gurney M, Mason MD, Tabi Z, Clayton A: Cancer exosomes trigger mesenchymal stem cell differentiation into pro-angiogenic and pro-invasive myofibroblasts. Oncotarget 2015, 6:715-731

49. Li X, Liu L, Shen Y, Wang T, Chen L, Xu D, Wen F: MicroRNA-26a modulates transforming growth factor beta-1-induced proliferation in human fetal lung fibroblasts. Biochem Biophys Res Commun 2014, 454:512-517

50. Sengupta S, Muir JG, Gibson PR: Does butyrate protect from colorectal cancer? J Gastroenterol Hepatol 2006, 21(Pt 2):209-218

51. Gibson PR, Rosella O, Wilson AJ, Mariadason JM, Rickard K, Byron K, Barkla DH: Colonic epithelial cell activation and the paradoxical effects of butyrate. Carcinogenesis 1999, 20: $539-544$

52. Singh B, Halestrap AP, Paraskeva C: Butyrate can act as a stimulator of growth or inducer of apoptosis in human colonic epithelial cell lines depending on the presence of alternative energy sources. Carcinogenesis 1997, 18:1265-1270 